Ferdinand, Siarl. "Almási, Gábor and Lav Šubarić, eds. 2015. Latin at the Crossroads of Identity. Leiden: Brill. 326 pp." Hungarian Cultural Studies. e-Journal of the American Hungarian Educators Association, Volume 9 (2016): http://ahea.pitt.edu DOI: 10.5195/ahea.2016.226

\title{
Almási, Gábor and Lav Šubarić, eds. 2015. Latin at the Crossroads of Identity. Leiden: Brill. 326 pp.
}

\section{Reviewed by Siarl Ferdinand, University of Wales Trinity Saint David}

In the decades between 1790 and 1850 Latin, the language of power, religion and culture in most of Europe for almost two millennia, finally lost its last secular domains in favor of a number of local languages in its last bastion, the lands of the Kingdom of Hungary, which then included the regions that later became the modern states of Hungary, Croatia, and Slovakia, as well as considerable parts of Serbia, Ukraine and Romania. Latin at the Crossroads of Identity, edited by Gábor Almási and Lav Šubarić, provides an excellent range of analyzes from multidisciplinary perspectives, by scholars of different national backgrounds, of the changes in the region following the echoes of the French Revolution and the advent of the Enlightenment to the epoch of Viennese Joseph II (1741-1790). The general claim that Almási, Šubarić, and the rest of contributors to this volume wish to prove is that the substitution of Latin in the region implied much more than an understandably traumatic language shift, since this transformation was a visible outcome of a new conception of the idea of national identity. For centuries most of the people who inhabited the Kingdom of Hungary shared a common identity, Hungarus, which was determined by its allegiance to the Hungarian king and not by their specific ethnicity, religion, or mother tongue. This order collapsed with the arrival to the region of new ideas of homogeneity emanating from the philosophies proper to the Age of Enlightenment, and their implementation by the ultimate power in Hungary, the Austrian Court, which saw Latin as an outdated tool that had to be substituted by German. As a counterforce, and without the neutral role that Latin played in the region, the Hungarus identity rapidly dissolved in favor of a number of local nationalisms with their languages and dialects, which further divided the Kingdom into several and often antagonist nationalities.

The book is made up of three main parts so that the first two, the politics of language and language dilemmas in education and media, both present the perspective of the main ethnic group of the Hungarian kingdom, the Magyars; while the third part deals with basically these same two topics but this time from the perspective of the "other Hungarians," namely, Croatians, Slovakians, the Serbians of Voivodina and the Romanians of Transylvania.

In the first chapter, István Margócsy describes the dramatic situation of the Hungarian language during the eighteenth century while, in contrast, Latin enjoyed one of its most glorious moments. Latin was not only the official language of the kingdom but also the language of culture and even the lingua franca among the inhabitants of Hungary (30). Therefore Latin continued to be necessary because, as Ambrus Miskolczy points out in Chapter Three, the identity of the inhabitants of the Countries of Saint Stephen's Crown was totally different from that of the citizens of the modern states that nowadays occupy the region (64). Magyars, Slavs, Germans and other groups of the time viewed themselves as Hungari, or in other words, as subjects of a kingdom in which no local language had any prevalence over the rest. This interethnic and almost sacred status was exclusively reserved to Latin. However, the decree by Emperor Joseph II to elevate German to the category of the sole official language in the entire

(cc) $\mathrm{Br}$

ULLS D-Serle
New articles in this journal are licensed under a Creative Commons Attribution 4.0 International License.

This journal is published by the University Library System of the University of Pittsburgh as part of its D-Scribe Digital Publishing Program and is cosponsored by the University of Pittsburgh Press 
Ferdinand, Siarl. "Almási, Gábor and Lav Šubarić, eds. 2015. Latin at the Crossroads of Identity. Leiden: Brill. 326 pp." Hungarian Cultural Studies. e-Journal of the American Hungarian Educators Association, Volume 9 (2016): http://ahea.pitt.edu DOI: 10.5195/ahea.2016.226

Empire, including the Kingdom of Hungary, awoke concern among prominent Hungarian circles that now demanded, on the one hand, the preservation of Latin as the historical language of the Hungarian Kingdom (as shown by Per Pippin Aspaas and László Kontler in Chapter Four) and, on the other, that Hungarian and not German should be the only language to substitute Latin, since no other language could help Hungary gain international recognition and become a modern nation (96). The latter point is well illustrated in Chapter Two within Henrik Hönich analysis of a pamphlet, published in 1790, addressing the necessity of implementing Hungarian in Hungary.

The second part of the book deals with the use of Latin and Hungarian in the fields of education and media. These two important fields reflect not only the attitudes of the most influential classes toward Latin and the local languages, but also the expectations of Hungarians for their country's future at a time when the way for the implementation of their language was not an easy one. Chapter Five, written by Teodora Shek Brnardić, exposes the ideology behind the preservation of Latin as a living language in Hungary. Contrarily to what happened in some countries during the period after the French Revolution in the last years of the eighteenth century, the Hungari did not view Latin as a retrograde element in their culture. On the contrary, for them it was a symbol of political freedom and they perceived the imposition of any other local language, including Hungarian, as an attack on common freedom (128). As for the media, meaning mainly the press, Latin continued to be the language most employed until it was overtaken by German and not Hungarian, as traced by Andrea Seidler in Chapter Six. The Magyar language only started to gain terrain when it was used in press as a means of developing a literary language (161-162). In Chapter Seven Piroska Balogh analyzes the paradoxes of the Latin press in eighteenth-century Hungary and shows that despite the pro-Hungarian-language turn of Magyar scholars and ruling classes, Latin continued to be viewed as the proper vehicle for transmitting serious ideas and knowledge such as science and diplomacy. Press was also an excellent tool to help students preserve and master the classical language. One of the last and most paradoxical examples of language and media struggles in Hungary of the time was Ephemerides Budenses, a journal published in Latin, presumably addressed to an international audience yet with strong pro-Hungarian-language content (181).

The last part of Latin at the Crossroads of Identity includes studies of the end of the era of Latin among some of the other main ethnicities of Royal Hungary. In Chapters Eight and Nine Lav Šubarić and Zvjezdana Sikirić Assouline analyze, each separately, the Croatian case; jointly their articles show how the Catholic southern Slavs, as well as the Magyars, strongly favored the continuity of Latin in official domains. However, the associated kingdoms of Croatia, Dalmatia and Slavonia were not immune to the tsunami of nationalism that had arrived to Hungary as a reaction to the Emperor's forced Germanization. Therefore, when the Magyars intended to substitute Latin by Hungarian in all of the Kingdom's counties, the Croatians reacted by demanding their freedom to either continue with Latin or implement a common Slavonic language (208). Their demands were not met and as a result the Slavs struggled to create a literary language and proceed toward official recognition of their language in the same way as did the Magyars in front of the Austrians.

The last three cases in the book's third part show noticeable differences when compared to the Magyar and Croatian cases. The Slavs of northern Hungary happily accepted the ideals of Pan-Slavism since, as Alexander Maxwell points out in Chapter Ten, they viewed themselves as simply Slavs. However, and as happened in the rest of the kingdom, Latin still remained both a popular language and the language of culture; moreover, the northern Slavs usually employed 
Ferdinand, Siarl. "Almási, Gábor and Lav Šubarić, eds. 2015. Latin at the Crossroads of Identity. Leiden: Brill. 326 pp." Hungarian Cultural Studies. e-Journal of the American Hungarian Educators Association, Volume 9 (2016): http://ahea.pitt.edu DOI: 10.5195/ahea.2016.226

Latin to discuss matters regarding their ethnicity. The Pan-Slavic feeling of northern Hungary, however, crashed with the nationalistic ideas that spread throughout the Austro-Hungarian Empire and which required more specific methods of expressing national/ethnic identity. This encounter set the bases for a new form of nationalism in the region based on new standards for the local Slavic dialects. This process eventually resulted in the birth of the Slovak nation and the recognition of its language (255). The Serbians were a very different case as they were southern Slavs like the Croatians yet followers of the Orthodox branch of Christianity. For the Serbians, then, the language of the Church and of culture was Old-Slavonic. Furthermore, as Nenad Ristović shows in Chapter Eleven, Latin was never much more than a minor trend in the long history of Serbian literature (277). Finally, in Chapter Twelve, Levente Nagy discusses the case of the Vlachs or Wallachians in Transylvania. Although they were the only nationality of Hungary that employed a neo-Latin language, Romanian, they were at a disadvantage compared to the other local nationalities since they were not even considered an established nation of Transylvania. Despite the efforts of a handful of Romanian-speaking scholars, Latin amongst this group never reached the status it had among the other Hungarian ethnicities. In addition, nationalism in Wallachia rapidly killed the motivation to implement Latin and instead brought in modern Romanian (306).

Latin at the Crossroads of Identity is highly recommendable and is a valuable volume not only for linguists, as some may deduce from just the name of the ancient Roman language in its title, but also for historians, sociologists, and a wider audience interested in topics related to Central Europe and all-European culture. It must be taken into consideration that the preparation of a volume in which the history and mentality of the nations of Central Europe are discussed is not an easy task due to rivalries and resentments that are still visible in the region amongst the groups under study. Nevertheless, the editors and contributors, themselves belonging to the region's various ethnicities, have produced an excellent work in which it would be difficult to find any offensive statements. The part that could have been better prepared, though, is the translation of all the non-English titles of works cited in this volume. While all the Hungarian titles of books, journals and articles are accompanied by their English translation, many of the Latin and German works and quotes are only cited in their original language, which may cause difficulties for non-readers of those languages. In all other respects Almási and Šubarić can be satisfied with having produced a volume that thoroughly explores the complex and dynamic relation between language and national identity within the Hungarian Kingdom of the turn of the eighteenth and nineteenth centuries. 